\title{
Cost-Effective Production of Powder Metallurgy Titanium Components for High-Volume Commercial Applications
}

Final Report for CRADA PNNL/234 with ADMA Products Inc.

CA Lavender

VS Moxson

VA Duz

October 2010

Pacific Northwest

NATIONAL LABORATORY

Proudly Operated by Battelle Since 1965 


\title{
DISCLAIMER
}

This report was prepared as an account of work sponsored by an agency of the United States Government. Neither the United States Government nor any agency thereof, nor Battelle Memorial Institute, nor any of their employees, makes any warranty, express or implied, or assumes any legal liability or responsibility for the accuracy, completeness, or usefulness of any information, apparatus, product, or process disclosed, or represents that its use would not infringe privately owned rights. Reference herein to any specific commercial product, process, or service by trade name, trademark, manufacturer, or otherwise does not necessarily constitute or imply its endorsement, recommendation, or favoring by the United States Government or any agency thereof, or Battelle Memorial Institute. The views and opinions of authors expressed herein do not necessarily state or reflect those of the United States Government or any agency thereof.

\author{
PACIFIC NORTHWEST NATIONAL LABORATORY \\ operated by \\ BATTELLE \\ for the \\ UNITED STATES DEPARTMENT OF ENERGY \\ under Contract DE-AC05-76RL01830
}

Printed in the United States of America
Available to DOE and DOE contractors from the
Office of Scientific and Technical Information,
P.O. Box 62, Oak Ridge, TN 37831-0062;
ph: (865) 576-8401
fax: $(865)$ 576-5728
email: reports@adonis.osti.gov

Available to the public from the National Technical Information Service

5301 Shawnee Rd., Alexandria, VA 22312

ph: (800) 553-NTIS (6847)

email: orders@ntis.gov $<$ http://www.ntis.gov/about/form.aspx $>$

Online ordering: http://www.ntis.gov

This document was printed on recycled paper. 


\title{
Cost-Effective Production of Powder Metallurgy Titanium Components for High-Volume Commercial Applications
}

Final Report for CRADA PNNL/234 with ADMA Products Inc.

\author{
CA Lavender \\ VS Moxson ${ }^{1}$ \\ VA Duz ${ }^{1}$
}

October 2010

Prepared for

the U.S. Department of Energy

under Contract DE-AC05-76RL01830

Pacific Northwest National Laboratory

Richland, Washington 99352

\footnotetext{
${ }^{1}$ ADMA Products, Inc., Hudson, Ohio
} 



\section{Contents}

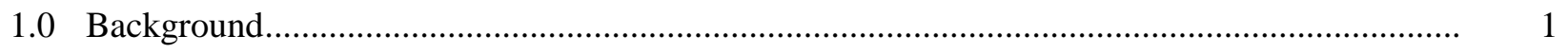

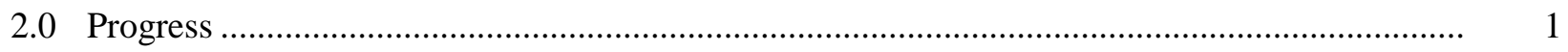

3.0 Partners Evaluation of Success ......................................................................................... 2

4.0 Future Plans and Commercialization Activities .................................................................... 3

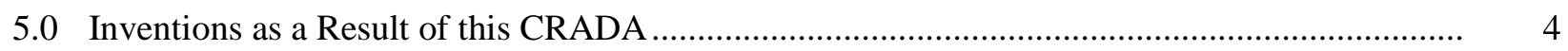

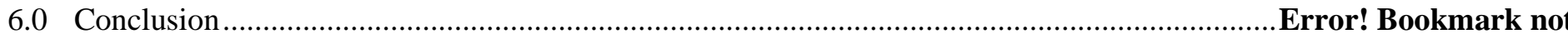

\section{Figure}

1 Plate Production of the Ti6Al4V Alloy Using Hydride Powder Developed During this CRADA 



\subsection{Background}

ADMA Products Inc. (ADMA) approached Pacific Northwest National Laboratory (PNNL) with a concept for the production of low-cost titanium components using a technology studied by the Institute for Metal Physics (IMP) in Kiev, Ukraine. ADMA recognized PNNL's role in the production of lightweight materials and components for automotive applications and wondered how PNNL's technology could be adapted for the production of titanium components that could meet the cost targets of the automotive industry. Given that the IMP was in the Ukraine and eligible for participation in the Initiative for Proliferation Prevention (IPP), now Global Initiatives for Proliferation Prevention (GIPP), there seemed to be a reasonable opportunity to propose the concept and establish U.S. Department of Energy (DOE) funding for the IMP and PNNL for technical development. ADMA would match DOE's dollars through a Cooperative Research and Development Agreement (CRADA). That CRADA is the subject of this report. The proposal was ultimately funded and the CRADA between ADMA and PNNL was established. PNNL managed the activities at IMP to support ADMA's development needs to achieve commercial sales of the titanium product.

\subsection{Progress}

The project is now complete. It was active for a little longer than the three-year limit due to the project's success in meeting technical and commercial targets. The IMP developed processing methods to produce a low-cost titanium powder using the Zaporozhye Titanium Magnesium Combine (ZTMK), a former Soviet Union titanium production facility located in Zaporozhye, Ukraine. This low-cost method, developed by the IMP along with State Titanium Research and Design Institute and ZTMK, used the existing titanium production reactors to produce a titanium hydride powder. The titanium hydride powder possessed better processing characteristics than pure titanium powder and could be produced at prices of close to $\$ 3.00 / \mathrm{lb}$, compared to $\$ 90.00 / \mathrm{lb}$ for conventional titanium powders. A conventional titanium production reactor was modified at ZTMK to allow the near-continuous production of titanium hydride powder. For the past three years, that single vessel has been producing titanium hydride powder at the rate of 35,000 lbs/yr. The powder is sold by ADMA.

Initially, the project was focused on the United States automotive industry. However, the implementation phase of the project struggled because little or no infrastructure exists for large-scale automotive component production due to the high cost of titanium, and in particular titanium powder products. So, the project shifted emphasis toward the commercial aviation industry, where there is an increasing demand for titanium and mounting pressure to reduce costs. The shift in emphasis resulted in the demand for additional alloys to be developed that were more readily used by the aerospace industry. Alloy development activities resulted in additional years of funding for the project allowing IMP to develop the parameters for making components from the new alloys. During this time, ADMA began working closely with the commercial aerospace industry and now has several components that meet the rigorous qualification required for a component to be used on aircraft. This lengthy qualification process is continuing without DOE/GIPP or PNNL participation. 
The process of aerospace qualification is complicated by the lack of a commercial titanium powder metallurgy industry. So, in addition to the development and qualification of the components, ADMA and the commercial aerospace industry must develop the standards and specifications for the new titanium materials produced from hydride powder. The process will take several years and ADMA continues to receive large numbers of development and qualification orders that easily consume the 35,000 lbs/yr produced at ZTMK.

ADMA has been pursuing the large-scale development of a variety of products, including extrusions, direct press and sinter components, and rolled plate. Figure 1 illustrates the magnitude of components under development by ADMA.

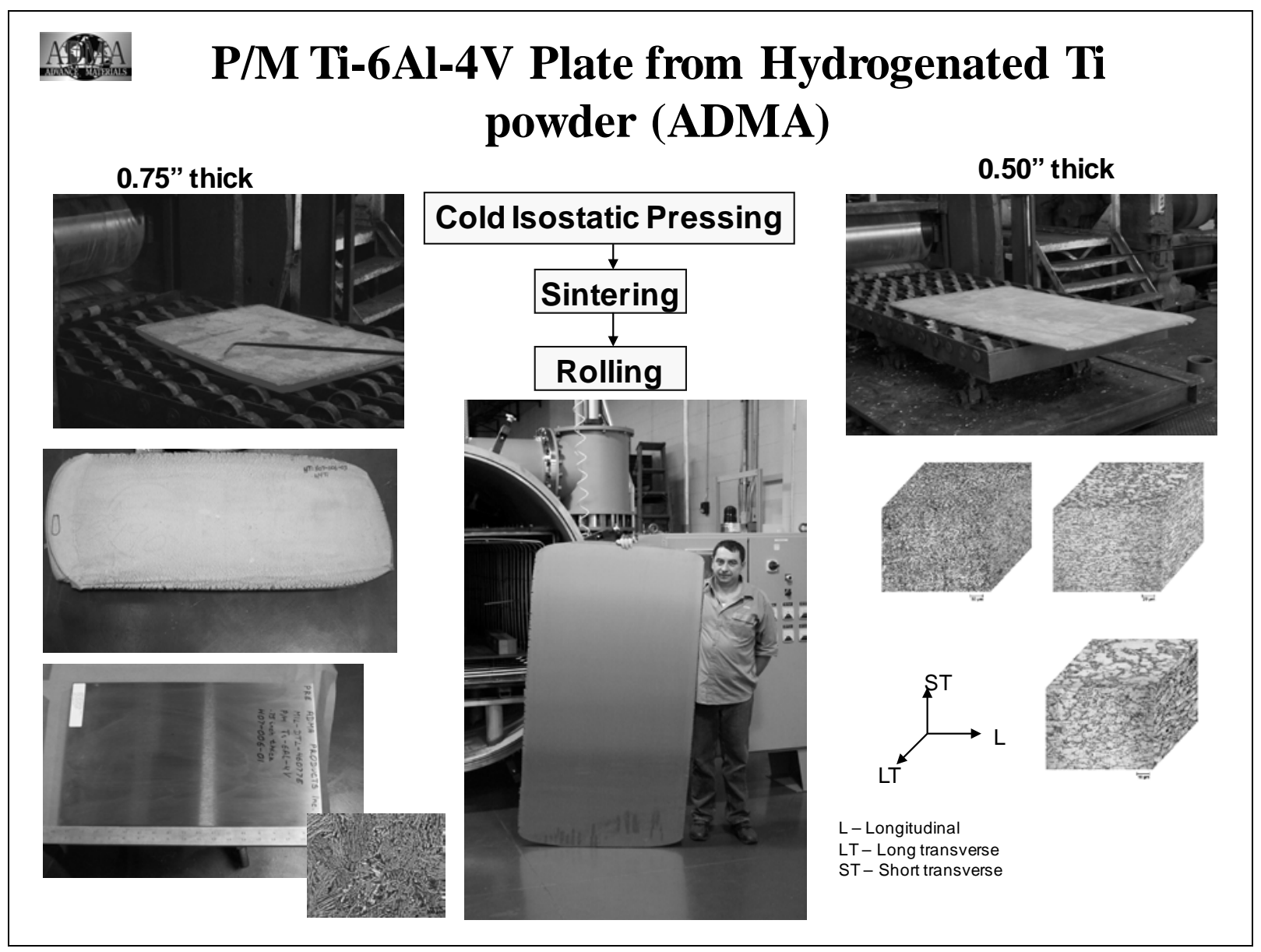

Figure 1. Plate Production of the Ti6Al4V Alloy Using Hydride Powder Developed During this CRADA. The starting billet for this plate was close to 500 lbs.

\subsection{Partners Evaluation of Success}

Although ADMA has yet to finalize a long-term production order for the titanium products, several qualifications are underway that could result in many tons of titanium component sales. ADMA considers the project a success and has a variety of related projects underway. The following is an abstract ADMA prepared for its last annual meeting with the United States Industry Coalition (USIC), 
which is the organization DOE commissioned to evaluate and promote the commercialization of the GIPP project portfolio,

\section{ADMA PRODUCTS INC., PNNL, AND THE INSTITUTE of METAL PHYSICS UKRAINIAN NATIONAL ACADEMY OF SCIENCES: A GIPP SUCCESS STORY!}

ADMA Products, Inc. is a manufacturer of powder metallurgy products made from titanium, zirconium, niobium, other advanced materials, and their alloys. ADMA specializes in the manufacture of porous and near full density powder metallurgy parts and offers extensive expertise in advanced material property design that meet the specific requirements of its customers. ADMA employs several processes in the manufacture of finished and semi finished titanium products including, but not limited to, die-pressing, cold isostatic pressing, direct powder rolling, sintering, coining, re-rolling, and high temperature rolling. ADMA has developed a variety of patented processes for industrial, aircraft, military, medical and commercial applications as it continues its work the Department of Energy, Department of Defense, every branch of our armed forces, every U.S. National Laboratory, NASA, every major aircraft manufacturer, heavy equipment manufacturers, heavy and light vehicle manufacturers, the medical and the energy industries.

As a participant in the GIPP Program, ADMA, in conjunction with the Pacific Northwest National Laboratory (PNNL), cooperated with the Institute of Metal Physics of the Ukrainian National Academy of Sciences to develop a cost-effective approach to reliably manufacture high quality titanium alloy parts for high-volume commercial applications. This has been a very successful relationship for ADMA, for the titanium industry, for Ukraine and America! Implementation of ADMA titanium products in automotive, aerospace, medical, energy and other industries have proven successful with promise of further applications as ADMA more fully moves into its additional role as a producer of the highest quality titanium powder. The titanium finished and semi finished products that ADMA will manufacture from ADMA titanium powder will exhibit the superior strength, corrosion resistance, and weight advantage of titanium with the final cost competitive with components hereto produced from inferior metals like steel, aluminum, and copper/nickel. Formerly high priced titanium will "come down" from its "cost is no object" applications and will be available for broader commercial, energy, and military use.

As a direct benefit of the GIPP Program, ADMA and its Ukrainian colleagues are generating revenues and a possible U.S.-Ukrainian joint venture is in development. Our Ukrainian colleagues have experienced significant economic benefit in a depressed industrial area. ADMA's success in reducing the cost of manufacturing titanium powder has increased demand for ADMA titanium products. ADMA will meet that demand by ordering additional titanium powder from its Ukrainian colleagues, and by expanding US capacity through construction of a titanium powder plant in Ohio. ADMA is currently in process of arranging organizing a meeting between U.S. defense industry representatives and our Ukrainian colleagues that could benefit all parties.

The technical experience of former Soviet weapons scientists in the GIPP Program, the participation of PNNL, and the technical and commercial know-how, and leadership of ADMA in the fields of powder metallurgy and lightweight material technology, has resulted in a true success!

\subsection{Future Plans and Commercialization Activities}

ADMA continues to develop the process without DOE involvement and is actively seeking private and government investments. ADMA plans to continue purchasing titanium hydride from the Ukraine. However, they have also begun to develop the capacity to produce the powder at ADMA. The following slides were extracted from ADMA's most recent presentation at USIC and describe a two-phased commercialization approach, resulting in a plant with a 44,000,000 lb/year titanium hydride capacity. The production capacity will be developed using reactor vessels built and delivered to ADMA by ZTMK 
during the course of the project, as shown in slides 2 and 3. Slides 1 and 4 describe a phased approach where ADMA will initially build a production facility around the intermediate vessel shown in slide 3 to produce 3,300,000 pounds of titanium hydride at their current facility in Hudson, Ohio. The second phase, described by slide 4, is the development of a large production facility (presently sited in Toledo, Ohio) that will produce nearly 44,000,000 pounds of titanium.

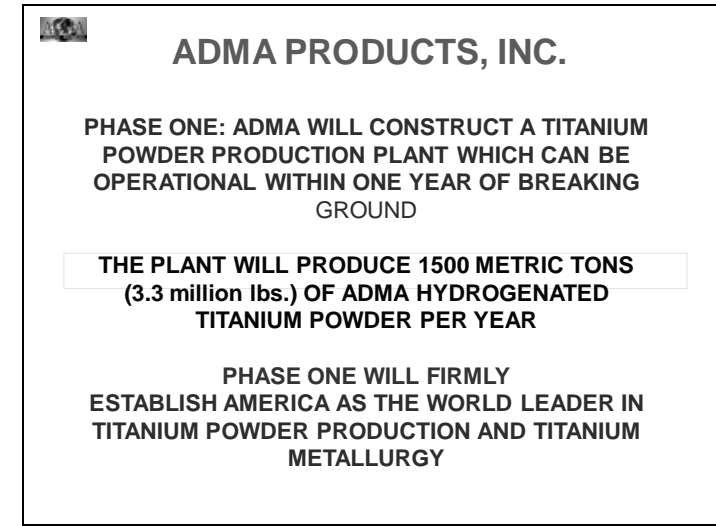

Slide 1

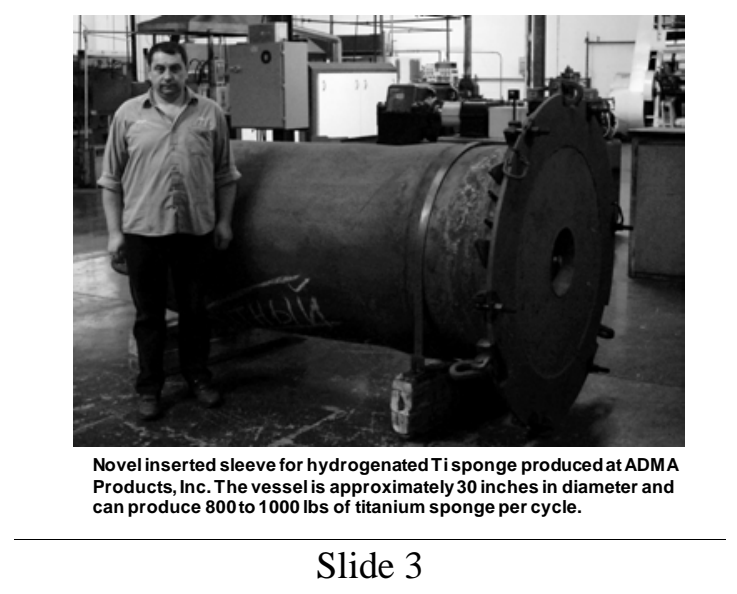

450. Hydrogenated Ti Powder Production

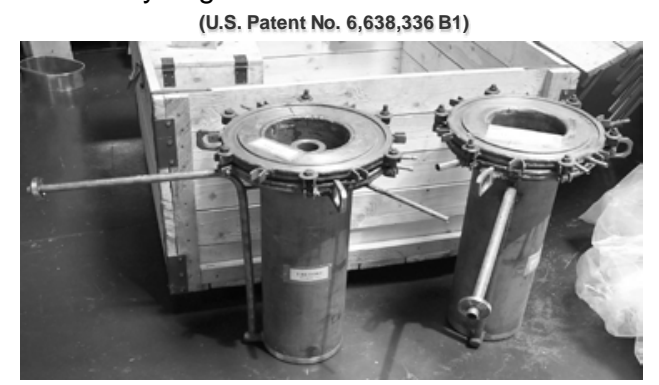

Lab-scale unit for hydrogenated Tisponge production at ADM A Products, Inc. The vessel is approximately 8 inches in diameter and will produce $10 \mathrm{lbs}$ of titanium powder per cycle.

Slide 2

18

ADMA PRODUCTS, INC.

PHASE 2: ADMA WILL CONSTRUCT A 20,000

METRIC TON (44 MILLION LBS) TITANIUM

POWDER PRODUCTION PLANT PLANNED TO FULLY OPERATIONAL BY 2015 - 2016

AS THE PHASE 2 PLANT IS UNDER CONSTRUCTION THE ADMA R\&D AND DESIGN TEAMS WILL HAVE LARGER FACILITIES ON THE DRAWING BOARD TO MEET INCREASED DEMAND FOR ADMA HYDROGENATED TITANIUM POWDER

\subsection{Inventions as a Result of this CRADA}

No new inventions were derived under this project. The work has largely focused on qualification of components due to early technical success and therefore did not lead to opportunities to create new intellectual property. As the production process develop undoubtedly many unique aspects of the process will be developed and patented. 


\subsection{Conclusion}

The CRADA project between ADAM and PNNL has been considered highly successful and is generating commercial sales at ADMA for a variety of aerospace components. Because titanium is used in demanding applications such as the aerospace industry the true commercial sales and sustainability will not be known for many years due to the rigorous qualification procedures that often take more than 10 years. ADMA continues to pursue this development and has an aggressive plan for commercialization. 


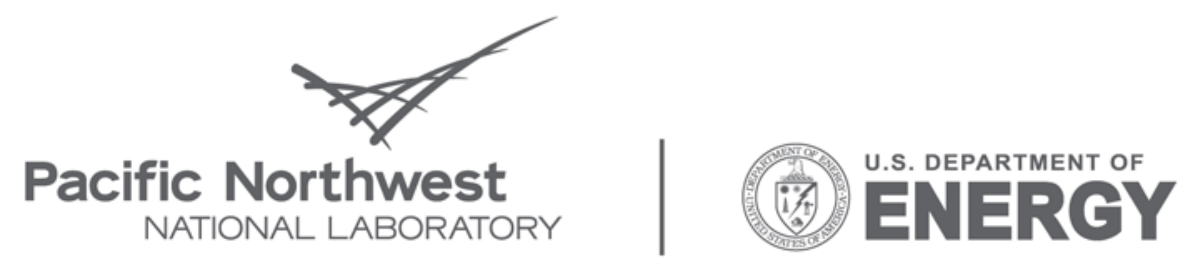

Proudly Operated by Battelle Since 1965

902 Battelle Boulevard

P.O. Box 999

Richland, WA 99352

1-888-375-PNNL (7665)

www.pnl.gov 